\title{
Glioblastoma-Induced Attraction of Endogenous Neural Precursor Cells Is Associated with Improved Survival
}

\author{
Rainer Glass, ${ }^{1 \star}$ Michael Synowitz,,${ }^{1,3 \star}$ Golo Kronenberg, ${ }^{2,4}$ Joo-Hee Walzlein, ${ }^{1}$ Darko S. Markovic, ${ }^{1}$ Li-Ping Wang, ${ }^{1}$ \\ Daniela Gast, ${ }^{2,5}$ Jürgen Kiwit, ${ }^{3}$ Gerd Kempermann, ${ }^{2,5 *}$ and Helmut Kettenmann ${ }^{1 *}$ \\ ${ }^{1}$ Cellular Neuroscience and ${ }^{2}$ Neural Stem Cell Groups, Max Delbrück Center for Molecular Medicine, 13092 Berlin, Germany, ${ }^{3}$ Department of Neurosurgery, \\ Helios Hospital Berlin, 13125 Berlin, Germany, ${ }^{4}$ Department of Psychiatry, Free University, Charité-Campus Benjamin Franklin, 14050 Berlin, Germany, \\ and ${ }^{5}$ Volkswagen Stiftung Research Group, Department of Experimental Neurology, Charité University Hospital, Humboldt University, 10117 Berlin, \\ Germany
}

Neural precursor cells contribute to adult neurogenesis and to limited attempts of brain repair after injury. Here we report that in a murine experimental glioblastoma model, endogenous neural precursors migrate from the subventricular zone toward the tumor and surround it. The association of endogenous precursors with syngenic tumor grafts was observed, after injecting red fluorescent proteinlabeled G261 cells into the caudate-putamen of transgenic mice, which express green fluorescent protein under a promoter for nestin (nestin-GFP). Fourteen days after inoculation, the nestin-GFP cells surrounded the tumors in several cell layers and expressed markers of early noncommitted and committed precursors. Nestin-GFP cells were further identified by a characteristic membrane current pattern as recorded in acute brain slices. 5-Bromo-2-deoxyuridine labeling and dye tracing experiments revealed that the tumor-associated precursors originated from the subventricular zone. Moreover, in cultured explants from the subventricular zone, the neural precursors showed extensive tropism for glioblastomas. Tumor-induced endogenous precursor cell accumulation decreased with age of the recipient; this correlated with increased tumor size and shorter survival times in aged mice. Coinjection of glioblastoma cells with neural precursors improved the survival time of old mice to a level similar to that in young mice. Coculture experiments showed that neural precursors suppressed the rapid increase in tumor cell number, which is characteristic of glioblastoma, and induced glioblastoma cell apoptosis. Our results indicate that tumor cells attract endogenous precursor cells; the presence of precursor cells is antitumorigenic; and this cellular interaction decreases with aging.

Key words: glioma; neuropathology; tumor; neural precursor; neurogenesis; gliogenesis; stem cells

\section{Introduction}

The ability to generate new neurons persists throughout mammalian life, but neurogenesis in the adult CNS is restricted to the dentate gyrus of the hippocampus and to the subventricular zone (Gage, 2000). The activity of these germinal centers declines with increasing age (Hallbergson et al., 2003; Maslov et al., 2004).

The migratory capacity and an apparent tropism of immortalized precursor cells for glioblastoma (Aboody et al., 2000) recommended these cells as gene carriers for brain tumor therapy, although it was not clear whether the observed tropism was based on precursor cell features or their immortalization. For example, immortalized cells from early postnatal neural precursors, genetically modified to overexpress interleukin-4, improved survival after inoculation into glioblastoma-bearing mice (Benedetti et

Received Sept. 3, 2004; revised Jan. 25, 2005; accepted Jan. 25, 2005.

This work was supported by Grant 01GZ0304 from the Bundesministerium für Bildung und Forschung (Förderkennzeichen) and by a grant from the Stiftung Neurochirurgische Forschung der Deutschen Gesellschaft für Neurochirurgie.

${ }^{*}$ R.G., M.S., G..K., and H.K. contributed equally to this work.

Correspondence should be addressed to Helmut Kettenmann, Max Delbrück Center for Molecular Medicine, Robert Rössle Strasse 10, 13092 Berlin, Germany. E-mail: hketten@mdc-berlin.de. DOI:10.1523/JNEUROSCI.5118-04.2005

Copyright $\odot 2005$ Society for Neuroscience $\quad 0270-6474 / 05 / 252637-10 \$ 15.00 / 0$ al., 2000; Noble, 2000). Interestingly, however, the unmodified control cells in that study enhanced survival, too. A recent study confirmed the effects on survival of in vitro expanded neural precursor cell lines administered into gliomas (Staflin et al., 2004). Currently, no gene therapy strategies have been approved for glioblastoma, and clinicians rely on the classic therapies, namely, surgery, chemotherapy, and cranial irradiation (Noble, 2000). However, glioblastomas cannot be completely removed by the classic therapies because of their high invasiveness, and the disease is therefore fatal within a short time (Kleihues et al., 1996; Holland, 2001). An important prognostic factor to predict the survival time of glioblastoma patients is age, and glioblastomas statistically peak in older patients of $\sim 55$ years (Kleihues et al., 1996).

In the present study, we show that endogenous neural precursor cells in the adult brain exhibit a strong tropism for glioblastomas in vivo and in vitro. Addition of neural precursors into glioblastoma grafts prolonged survival in vivo, and coculturing of precursors with G261 cells promoted tumor cell death. Grafting of G261 cells into animals of increasing age resulted in a more and more severe course of pathology. This inverse correlation between the age-related decline of precursors concomitant with the increased aggressiveness of glioblastomas is discussed. 


\section{Materials and Methods}

Animals. Wild-type C57BL/6 mice (Charles River Laboratories, Schöneiche, Germany) and nestin-green fluorescent protein (GFP) mice [genetic background of C57BL/6)(9)] were bred at a local facility. Animals were handled according to the Policies on the Use of Animals and $\mathrm{Hu}-$ mans in Neuroscience Research revised and approved by the Society for Neuroscience in January 1995.

Astrocyte and fibroblast cell cultures. The nontumorigenic fibroblast cell line scrc-1008 was established from C57BL/6 mouse embryos [American Type Culture Collection (ATCC), Manassas, VA] and cultured in DMEM (Invitrogen, Gaithersburg, MD) with additives. Cultures were prepared from the brains of newborn C57BL/6 mice as described previously (Lyons and Kettenmann, 1998) with small modifications. Briefly, brain tissue was freed from blood vessels and meninges, trypsinized, and gently triturated with a fire-polished pipette in the presence of $0.05 \%$ DNAase (Worthington, Freehold, NJ). After washing twice, cells were cultured in $75 \mathrm{~cm}^{2}$ flasks and for astrocyte cultures also directly plated on poly-L-lysine (100 $\mu \mathrm{g} / \mathrm{ml}$; Sigma, Deisenhofen, Germany)-coated glass coverslips (diameter, $15 \mathrm{~mm}$ ) at densities of $3-5 \times 10^{4}$ cells per coverslip kept in 10-cm-diameter dishes using DMEM supplemented with $10 \%$ fetal calf serum (FCS), $2 \mathrm{~mm}$ L-glutamine, $100 \mathrm{U} / \mathrm{ml}$ penicillin, and 100 $\mu \mathrm{g} / \mathrm{ml}$ streptomycin. One day later, cultures were washed twice with HBSS to remove cellular debris. The cultures typically showed $>90 \%$ cells positive for glial fibrillary acidic protein (GFAP).

Glioblastoma cell line. G261 glioblastoma cells (isogenic to C57BL/6 mice; National Cancer Institute, Frederick, MD), F98 glioblastoma cells (from Fischer rats), and the human U373 glioblastoma cell line (both from ATCC) were grown in DMEM (Invitrogen) with additives. For in vivo experiments, cells were resuspended in Neurobasal medium (NB-2; Invitrogen) without additives.

Stably transfected cells. G261, F98, and U373 glioblastoma cells were transfected with the red fluorescent protein (pDsRed2-N1) vector purchased from Clontech (Heidelberg, Germany).

Adult neural precursor cell preparation. Adult neural precursor cells (A-NPCs) were cultured from wild-type C57BL/6 mice and from nestinGFP mice both at postnatal day 90 (P90) (Palmer et al., 1997). Briefly, brains containing the subventricular zone (but not the hippocampus or olfactory bulbs) were cultured as neurospheres in NB-2 supplemented with B27 (both from Invitrogen), $20 \mathrm{ng} / \mathrm{ml}$ recombinant human epidermal growth factor, and $20 \mathrm{ng} / \mathrm{ml}$ human recombinant fibroblast growth factor-2 (both from R \& D Systems, Minneapolis, MN). Nestin-GFP expression of neurospheres and their ability to generate neurons and glia were routinely checked.

Explant cocultures. Cocultures with explants from the subventricular zone were performed as described previously (Zhang et al., 2003). Briefly, the subventricular zones were microdissected from $250 \mu \mathrm{m}$ brain slices of P0 nestin-GFP-transgenic mice. These were cocultured with threedimensional G261-DsRed cell aggregates, which contained 50,000 cells. Tissues were put together on a transwell, embedded in Matrigel (1:10 diluted in DMEM), and cocultured for 5-7 $\mathrm{d}$ in chemically defined serum-free medium (DMEM and F-12 complemented with $20 \mu \mathrm{g} / \mathrm{ml}$ human transferrin, $100 \mu \mathrm{m}$ putrescin, $30 \mathrm{~nm}$ sodium selenite, $1 \mathrm{~nm}$ triiodothyronine, and $60 \mathrm{U} / \mathrm{L}$ insulin) under $5 \% \mathrm{CO}_{2}$. The medium was changed every third day. As controls, subventricular zone explants were cocultured with cortical tissue.

Cell coculture experiments. G261-DsRed cells $\left(10^{4}\right)$ were cocultured on coverslips with NPCs, isolated from nestin-GFP transgenic mice, in ratios of 1:1 and 1:3. After $72 \mathrm{~h}$, the cells were fixed with $4 \%$ paraformaldehyde, and the nuclei were stained with 4',6-diamidino-2-phenylindole (DAPI). The total cell number was determined by using a fluorescence microscope. Cells labeling for DsRed and DAPI were counted per optical field; the areas for cell counting were chosen in a random manner; and on each coverslip, 10 nonoverlapping areas were counted. One experimental group consisted of cell counts from three coverslips, and each series of experiments was repeated three times. Control groups consisted of coculture of G261 cells with fibroblasts and astrocytes in a ratio of 1:3.

To establish adherent cell cultures of G261 cells in NPC-conditioned medium, $2 \times 10^{4}$ glioblastoma cells were initially seeded in DMEM, 10\%
FCS, $30 \mathrm{mg} / 100 \mathrm{ml}$ glutamine, and $0.15 \mathrm{mg} / \mathrm{ml}$ neomycin. After $1 \mathrm{~d}$, the serum-containing medium was removed, and cells were washed three times with PBS and cultured in the NPC-conditioned medium for $72 \mathrm{~h}$. Fixation, staining, and cell counting were performed as described above. As controls, G261 cells were cultured in fibroblast- and astrocyteconditioned medium for $72 \mathrm{~h}$.

To quantify apoptotic glioblastoma cells in cocultures with neural precursors, astrocytes, or fibroblasts, cells were seeded and cultivated as described above. Apoptosis was determined with a fluorescent cell death detection kit [terminal deoxynucleotidyl transferase-mediated biotinylated UTP nick end-labeling (TUNEL) kit; Roche Biosciences) according to the manufacturer's instructions. Then, TUNEL-positive nuclei of DsRed-expressing cells were counted as described above.

Gelatin zymography. Activity of gelatinases was analyzed with a gelatin zymography procedure adapted from that of Heussen and Dowdle (1980). G261 cells were grown in serum-free medium, and samples from conditioned medium were taken after $24 \mathrm{~h}$ of culturing. The tumorcontaining brain tissue was then lysed in $0.5 \mathrm{~m}$ Tris, $\mathrm{pH} 6.8,20 \%$ glycerol, $4 \%$ SDS, and $0.1 \%$ Triton X-100 (Tx-100), and the samples were loaded into a $7.5 \%$ SDS gel containing $1 \%$ gelatin. After electrophoresis $\left(4^{\circ} \mathrm{C}, 90\right.$ $\mathrm{V})$ the gel was washed two times for $15 \mathrm{~min}$ in $2.5 \% \mathrm{Tx}-100$ washing solution and incubated overnight in developing buffer ( $50 \mathrm{~mm}$ Tris, $\mathrm{pH}$ 7.6, $10 \mathrm{~mm} \mathrm{CaCl}_{2}, 50 \mathrm{~mm} \mathrm{NaCl}$, and $0.05 \%$ Brij 35). Next, the gel was stained for $30 \mathrm{~min}$ in $0.5 \%$ Coomassie blue solution and later destained with $40 \%$ methanol and $10 \%$ acetic acid.

Inoculation of G261 cells for immunocytochemistry. Anesthetized wildtype and nestin-GFP mice were immobilized and mounted into a stereotactic head holder (David Kopf Instruments, Tujunga, CA), in the flatskull position. Approximately $1 \mathrm{~mm}$ anterior and $1.5 \mathrm{~mm}$ lateral to bregma (for young animals) or $1.5 \mathrm{~mm}$ posterior and $1.5 \mathrm{~mm}$ lateral to bregma (for old animals), a $1 \mu \mathrm{l} 30$ gauge gas-tight syringe (Hamilton, Reno, NV) was then inserted to a depth of $4 \mathrm{~mm}$ and retracted to a depth of $3 \mathrm{~mm}$ from the dural surface, and $1 \mu \mathrm{l}\left(2 \times 10^{4}\right.$ cells $\left./ \mu \mathrm{l}\right)$ of DsRedG261 cell suspension was injected.

5-Bromo-2-deoxyuridine injections. For 5-bromo-2-deoxyuridine (BrdU) labeling experiments, animals received intraperitoneal injections of $50 \mathrm{mg}$ of BrdU/ $\mathrm{kg}$ of body weight at a concentration of $10 \mathrm{mg} / \mathrm{ml} \mathrm{BrdU}$ (Sigma, St. Louis, MO) in sterile $0.9 \% \mathrm{NaCl}$ solution twice daily for $3 \mathrm{~d}$ until $24 \mathrm{~h}$ before the operation.

1,1-Dioctadecyl-6,6-di-(4-sulfophenyl) 3,3,3,3-tetramethylindocarbocyanine injections. We applied intraventricular injections of $0.2 \%(\mathrm{w} / \mathrm{v})$ 1,1-dioctadecyl-6,6-di-(4-sulfophenyl) 3,3,3,3-tetramethylindocarbocyanine (DiI; Molecular Probes, Eugene, OR) in dimethylsulfoxide $\sim 0.7$ $\mathrm{mm}$ posterior and $0.8 \mathrm{~mm}$ lateral to bregma on the left side using $0.5 \mu \mathrm{l}$ DiI at a depth of $2.8 \mathrm{~mm}$ from the dural surface. Tumor injections were performed as described in the right hemisphere. Twenty nestin-GFP mice with or without glioblastomas were used to prove the reliability of the DiI injection technique and were killed after $6 \mathrm{~h}$ and 1,4 , and $7 \mathrm{~d}$ to observe the intensity and the distribution of DiI.

Survival study. Two groups of wild-type C57BL/6 mice (one group at P25 and the other at P180) received G261 cells alone. Another group of P180 mice received a mixture of G261 cells plus A-NPCs, with stereotactic operations as indicated. Cell numbers were for mixed cell suspensions $\left(6 \times 10^{4}\right.$ precursor cells $/ 4 \mu \mathrm{l}$ plus $2 \times 10^{4} \mathrm{G} 261$ cells $/ 1 \mu \mathrm{l}$; total volume, $5 \mu \mathrm{l})$ and for tumor cells alone $\left(2 \times 10^{4}\right.$ cells $\left./ 5 \mu \mathrm{l}\right)$. Accumulation of exogenous (nestin-GFP-positive) A-NPCs around glioblastomas in a manner similar to that of endogenous A-NPCs was observed (data not shown).

Immunofluorescence. All staining was performed on $40 \mu \mathrm{m}$ freefloating sections, and immunofluorescent triple labeling was performed as described previously (Kempermann et al., 2003) with the following primary antibodies: mouse anti-brevican (BD Transduction Laboratories, Heidelberg, Germany); rat anti-BrdU (Biozol, Eching, Germany); goat anti-doublecortin (Santa Cruz Biotechnology, Heidelberg, Germany); rabbit anti-fibronectin (Sigma); guinea pig anti-GFAP (Advanced ImmunoChemical, Long Beach, CA); rabbit anti-GFP (Abcam, Cambridgeshire, UK); goat anti-GFP (DPC, Bad Nauheim, Germany); mouse anti-DsRed (Abcam); rabbit anti-Ki67 (Novocastra Laboratories Ltd., Newcastle, UK); rabbit anti-NG-2 (Chemicon, Temecula, CA); rabbit 
anti-S100 $\beta$ (Swant, Bellinzona, Switzerland); mouse anti-rat CD11b (Serotec, Oxford, UK); goat anti-metalloprotease-2 (Santa Cruz Biotechnology); polyclonal rabbit anti-Musashi (Chemicon); mouse antipolysialated neural cell adhesion molecule (PSA-NCAM; Chemicon); mouse anti-calbindin (Swant); monoclonal mouse anti-O4 (Chemicon);
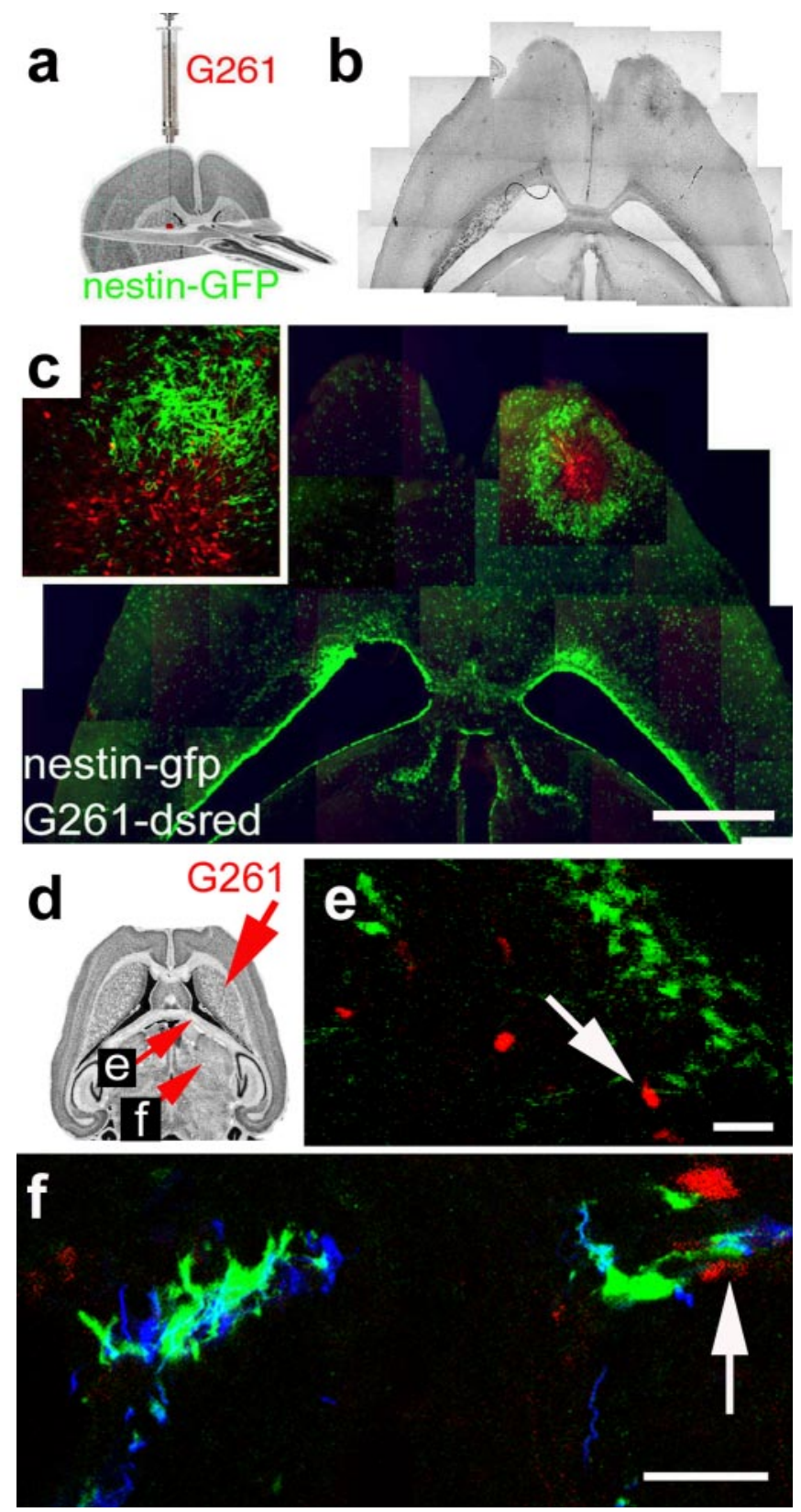

Figure 1. Endogenous neural precursor cells surround experimental glioblastomas. $\boldsymbol{a}$, Illustration of the procedure and the location for grafting of G261-DsRed cells. $\boldsymbol{b}$, Phase contrast composite image corresponding to the image in c displaying the brain morphology $14 \mathrm{~d}$ after tumor inoculation into a nestin-GFP mouse. c, Fluorescence microscope composite image of a horizontal section through the brain, with nestin-GFP cells (green) accumulating around a tumor (red G261 glioblastoma cells) in the right forebrain. Neural precursor cells in the contralateral hemisphere are primarily restricted to the subventricular zone. A magnified confocal image ( $\boldsymbol{c}$, inset) shows nestin-GFP-positive cells at the border zone of the glioblastoma. $\boldsymbol{d}$, Fourteen days after tumor inoculation, some G261-DsRed cells invaded into the fimbria of the hippocampus; the arrow refers to the image in e. Other G261-DsRed cells invaded the lateral thalamus; the arrow refers to the image in $f$.e, Nestin-GFP-expressing precursors associate with glioblastoma cells deeply invading into the brain. $\boldsymbol{f}$, Nestin-GFP- and doublecortin-coexpressing neural precursors track down DsRed-expressing glioblastoma cells in the thalamus. Scale bars: c, $1 \mathrm{~mm} ; \boldsymbol{e}, \boldsymbol{f}, 40 \mu \mathrm{m}$ and rabbit anti-TUC-4 (turned on after division, $64 \mathrm{kDa} / \mathrm{Unc}-33$-like protein/collapsing response mediator protein 4; Chemicon). FITC-, RhodX-, and $N, N^{\prime}$-biscarboxypentyl-5,5'-disulfonatoindodicarbocyanine-conjugated secondary antibodies were from Jackson ImmunoResearch (West Grove, PA).

Confocal microscopy. All confocal microscopy was performed using a spectral confocal microscope (TCS SP2; Leica, Nussloch, Germany). Ap-

\section{operated P25}

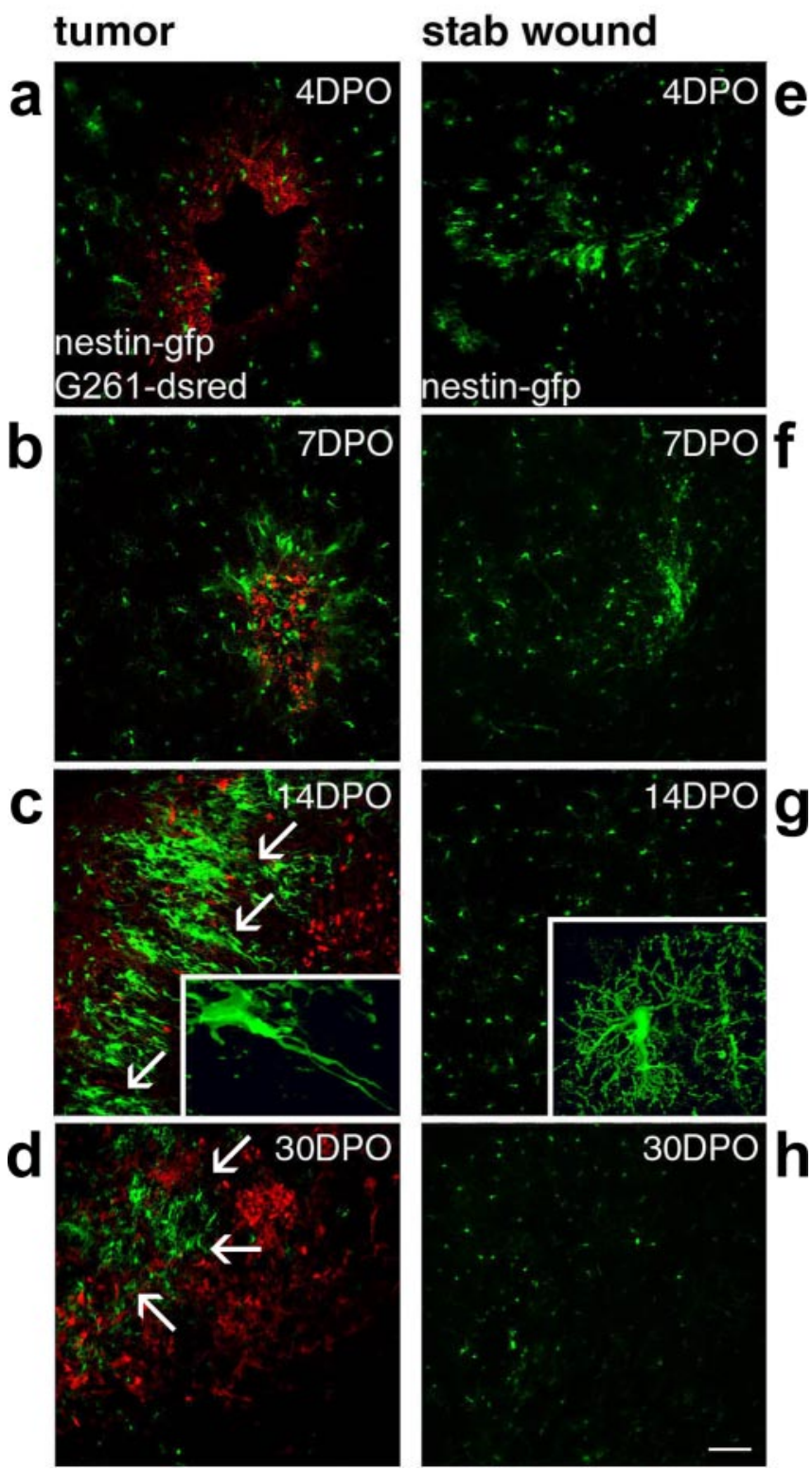

Figure 2. Time course of the precursor cell attraction to glioblastomas. Time course and intensity of the accumulation of nestin-GFP cells at glioblastomas $(\boldsymbol{a}-\boldsymbol{d})$ or at stab wounds $(\boldsymbol{e}-\boldsymbol{h})$ are different (in mice of P25). At $4 \mathrm{~d}$ postoperatively (4DP0), the injection canals were still visible $(\boldsymbol{a}, \boldsymbol{e})$; later on, these were identified stereotactically. At 4DP0 and 7DP0, G261-DsRed cells started to form tumors $(\boldsymbol{a}, \boldsymbol{b})$, but nestin-GFP cells accumulated similarly at tumors and controls $(\boldsymbol{e}, \boldsymbol{f})$. This changed dramatically at 14DPO. In controls of 14DPO ( $\boldsymbol{g})$ and 30DPO (h), no nestin-GFP-positive cells remained at the lesion; cells scattered throughout the lesioned hemisphere were stellate in morphology ( $\boldsymbol{g}$, inset). G261-DsRed-induced glioblastomas reached a diameter of $>1 \mathrm{~mm}$, closely encircled by a rim of neural precursor cells forming a layer of at least $200 \mu \mathrm{m}$; the tumor border is indicated by arrows in c. These nestin-GFP-positive cells typically had a bipolar morphology (c, inset). In glioblastoma-bearing mice at 30DP0, the continuous layer of nestin-GFP-positive cells around the tumor was absent, and the tumors had primarily increased in size; the tumor border is indicated by arrows in $\boldsymbol{d}$. Scale bar, $120 \mu \mathrm{m}$. 
propriate gain and black level settings were determined on control tissues stained with secondary antibodies alone. Overview images were processed with Photoshop version CS (Adobe, San Jose, CA), and colocalization images were processed with Volocity version 2.6.1 (Volocity, Lexington, MA).

Cell counting and unbiased stereology. In every 12th axial section $1.8-4.2 \mathrm{~mm}$ from dural surface, we sampled the area that was primarily infiltrated by the tumor; anteriorly, we excluded the olfactory bulb, and posteromedially, we excluded the hippocampal formation, at the dorsal end of which we cut laterally toward the surface of the hemisphere. Cell counts were determined in an unbiased approach using an optical fractionator procedure (StereoInvestigator; MicroBrightField Inc.) The coefficient of error of the probe was consistently $\leq 0.08$. Tumor volume was quantified according to the Cavalieri principle by determining the tumor area in every sixth $40 \mu \mathrm{m}$ brain slice and then multiplying by $6 \times 40 \mu \mathrm{m}$. For further phenotypic analysis of nestin-GFP-positive cells, we randomly selected in the vicinity of the tumor 100 cells per section from six different tissue sections, repeated with tissue from three different mice.

Patch clamping of acute brain slices. Electrophysiology of acute brain slices was performed as described previously (Filippov et al., 2003). Briefly, forebrain slices including a tumor mass were acutely isolated from nestin-GFP transgenic mice after stereotactic operation, DiI injection, and G261 tumor induction. Brains were cut into $150-\mathrm{mm}$-thick coronal slices. Membrane currents were measured with the patchclamp technique in the whole-cell voltageclamp configuration (Hamill et al., 1981). Capacitive currents and series resistance compensation were performed. Pipette resistance was 4-8 M $\Omega$. Series resistance was typically $16-33 \mathrm{M} \Omega$, and series compensation was set to $80 \%$. Cells located $\sim 10-30 \mu \mathrm{m}$ below the surface of the slice were visible with water immersion optics using a bandpass filters enhanced GFP and DsRed. Cells were photographed using a CCD camera (Watek Instruments) for recording cell size, location, and morphology. After the patch-clamp recording, the dye Alexa Fluor 594 was used to confirm that the cell that was patched was a GFP-labeled cell.

Statistical analyses. Nonparametric analyses for survival were performed with SPSS version 11.0 (SPSS Inc., Chicago, IL). Significant differences were determined by the Cox-Mantel test and Cox F test.

\section{Results}

Endogenous neural precursors accumulate at glioblastomas To identify endogenous neural precursor cells, we used transgenic mice expressing enhanced green fluorescent protein under the control of the nestin promoter (Lendahl, 1997; Kempermann et al., 2003). In the adult brain, nestin is only expressed in neural precursor cells, and the GFP fluorescence served as a marker for this cell population (nestin-GFP-positive cells). Cells of the glioblastoma line G261 were stably transfected to express DsRed and were inoculated into the caudate-putamen of the transgenic mice (syngenic to the background of the tumor model) (Fig. 1a,
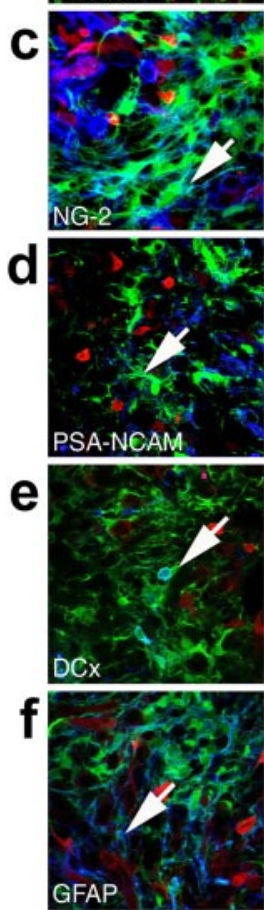
reconstructions, $6 \mu \mathrm{m}$.
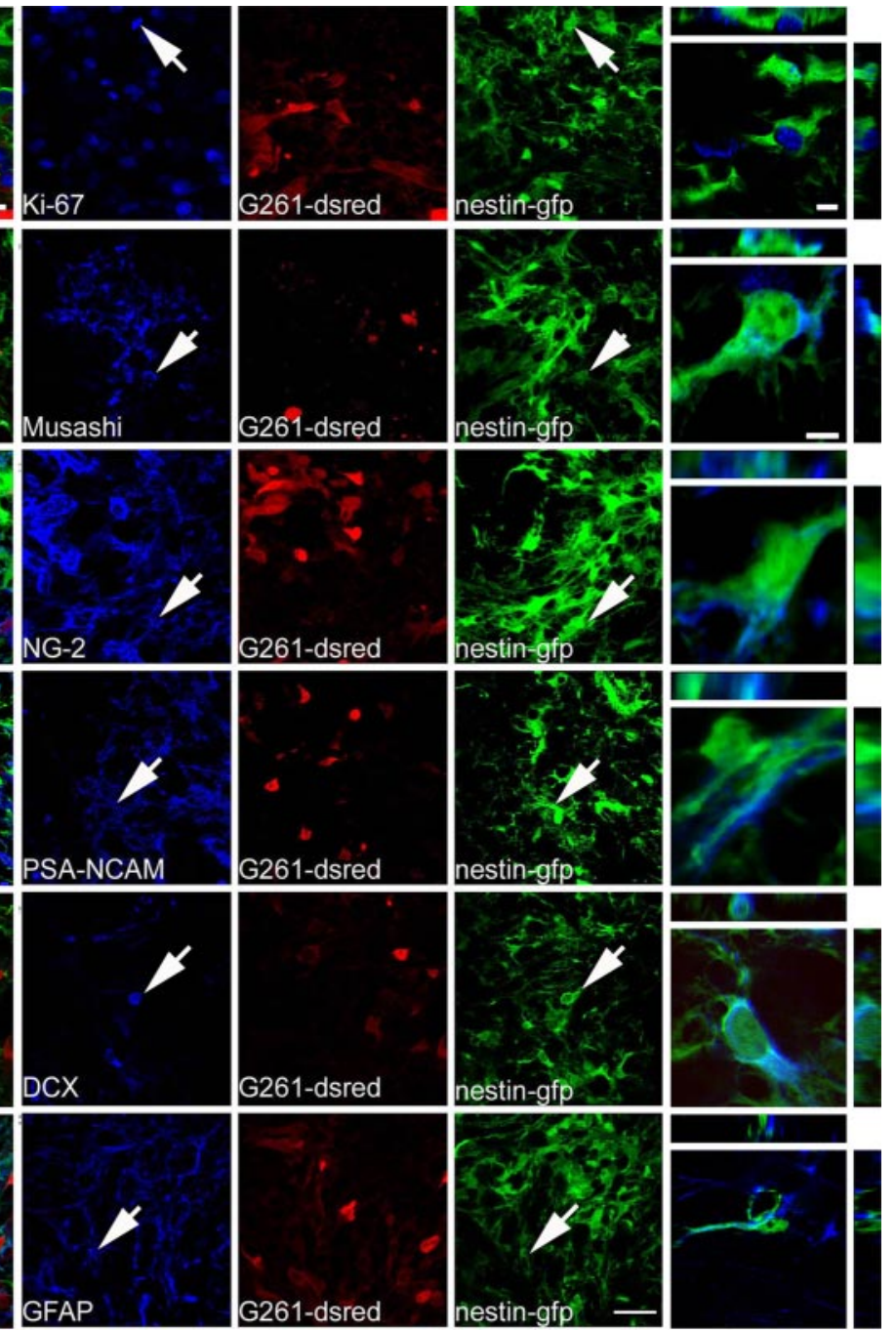

Figure 3. Nestin-GFP-positive cells accumulating around experimental glioblastomas are characterized as genuine neura precursors. G261-DsRed cells induced glioblastomas (red) in the caudate-putamen of P25 nestin-GFP mice (nestin-GFP cells in cells is demonstrated by arrows in the micrographs and by 3 D reconstructions of single cells. $\boldsymbol{a}$, The cell cycle protein Ki67 (a marker for cell proliferation) labeled nuclei of numerous glioblastoma cells and many nestin-GFP cells. $\boldsymbol{b}$, Musashi 1, marking neural membranes and in the cytosol of nestin-GFP-positive cells and glioblastomas. $\boldsymbol{d}$, Staining for the neural precursor cell marker not found on glioblastoma cells. $e$, Immunolabeling for $D C x$, which controls migration in neural precursors, was only detected in the cytoplasm of nestin-GFP-positive cells in the germinal centers and around tumors. $\boldsymbol{f}$, The intermediate filament GFAP, which expressing only GFAP but not nestin-GFP were observed in the area bearing G261-DsRed cells. Scale bars: overviews, $25 \mu \mathrm{m} ; 3 \mathrm{D}$

scheme). This approach allowed us to distinguish whether precursor cells originated from the tumor or from the germinal zones of the recipient.

Two weeks after inoculation of glioblastoma cells into the caudate-putamen of adult mice ( $25 \mathrm{~d}$ old), tumors had developed. Nestin-GFP-positive cells were highly abundant in the tumor-containing hemisphere compared with the contralateral side and surrounded the tumor by forming multiple cell layers (Fig. 1b,c). In this tumor border zone, glioblastoma and nestinGFP-positive cells were intermingled. A minor population of glioblastoma cells evaded into the surrounding parenchyma, beyond the rim of the nestin-GFP-positive cell layer. Similar results were obtained after inoculation into the anterior striatum and 
a
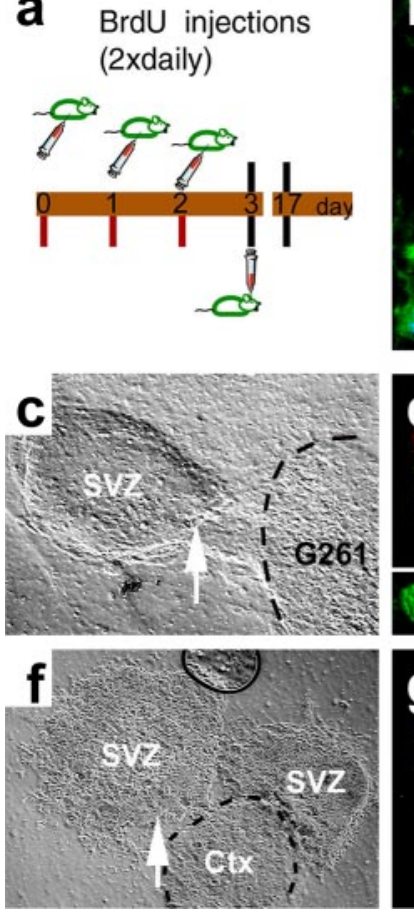
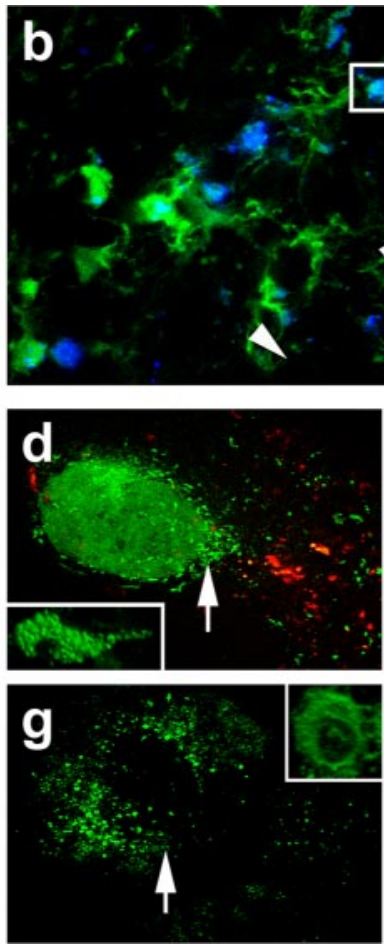
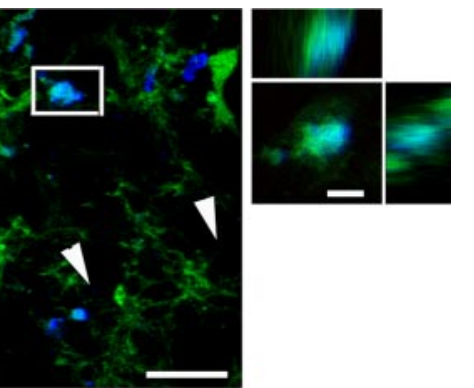

bronectin was rarely observed (supplemental Fig. $1 c, d$, available at www.jneurosci. org as supplemental material). Furthermore, expression of brevican is absent from low-invasive 9L gliosarcomas (Zhang et al., 1998) but is abundant at the invasion front of G261 glioblastomas, as is the proinvasive metalloproteinase-2 (supplemental Fig. $1 e-g$, available at www.jneurosci.org as supplemental material) (Koul et al., 2001).
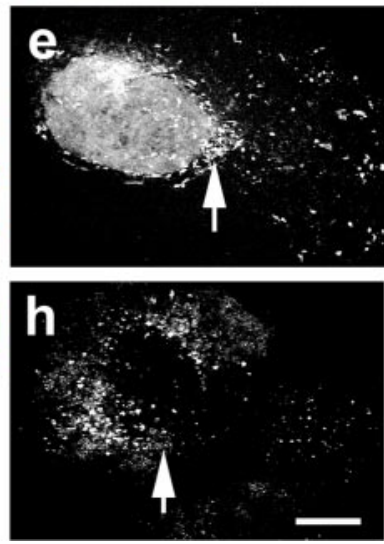

Figure 4. Neural precursor cells from the germinative center, i.e., the subventricular zone, exhibit a strong tropism for glioblastomas. Neural precursor cells labeled preoperatively $(\boldsymbol{a})$ appear around a glioblastoma $(\boldsymbol{b})$. Many nestin-GFP cells at the tumor border ( $\boldsymbol{b}$, arrowheads) are labeled for BrdU (blue). Colabeling for nestin-GFP and BrdU of a single cell in $\boldsymbol{b}$, which is highlighted by a rectangle, was confirmed by $3 \mathrm{D}$ reconstruction. $c$, An explant from the subventricular zone (SVZ) of a nestin-GFP mouse was exposed to a 3D cell aggregate of DsRed-expressing glioblastoma cells (G261); the outlines of the tumor are indicated by a dashed line. $\boldsymbol{d}$, After $5 \mathrm{~d}$ of coculture, many GFP-expressing precursors have migrated into the area occupied by the tumor; these migrating neural precursors (indicated by an arrow) have a bipolar morphology. $\boldsymbol{e}$, Single-channel micrograph indicating that neural precursors distribute exclusively into the glioblastoma. $f$, Two explants from the SVZ were exposed to each other and to a tissue from the cortex (Ctx; indicated by a dashed line) over a culture period of $5 \mathrm{~d}$; all tissues were derived from nestin-GFP mice. $\boldsymbol{g}$, Neural precursors from the subventricular zone stayed stationary and preserved a rounded cell morphology (single stationary cell indicated by arrows). $\boldsymbol{h}$, Single-channel micrograph showing absence of any precursor cell migration. Scale bars: $\boldsymbol{b}, 20 \mu \mathrm{m} ; 3 \mathrm{D}$ reconstruction, $5 \mu \mathrm{m} ; \boldsymbol{h}, 150 \mu \mathrm{m}$.

after xenotransplantation of fluorescently labeled U373 and F98 cell lines (results not shown). Invading G261 cells migrated far into the brain parenchyma (e.g., into the striatum). These invading glioblastoma cells were frequently associated with nestin-GFP positive cells, indicating that neural precursors also have a strong tropism for glioblastomas outside the main tumor mass (Fig. $1 d-f$ ).

\section{Characterization of the glioblastoma model}

Experimental glioblastomas were induced with three glioblastoma cell lines from different species (U373, from human; F98 from rat; and G261 from C57BL/6 mouse). The highly invasive phenotype of these tumor cells has been established previously (Westermark et al., 1973; Ponten and Westermark, 1978; Arnhold et al., 2003; Wheeler et al., 2003). We verified that G261 cells kept their glioblastoma phenotype in vitro and in vivo. G261 cells did not undergo a mesenchymal drift in culture or after injection into the brain and maintained their invasiveness. Low expression of GFAP and high expression of fibronectin would indicate gliosarcomas, which have a mesenchymal character (Iwasaki et al., 1992), whereas in glioblastomas, only low levels of fibronectin are secreted (Liu et al., 2000). Expression of GFAP was consistently detected in G261 cells, albeit at a lower level than in astrocytes or neural precursors (supplemental Fig. 1a,b, available at www. jneurosci.org as supplemental material), and expression of fi-

\section{Time course of the neural precursor} cell accumulation

To study the time course of nestin-GFPpositive cell aggregation around the tumor, animals were killed 4, 7, 14, and $30 \mathrm{~d}$ after tumor cell inoculation. Few nestinGFP-positive cells were found dispersed around the inoculation site at day 4 (Fig. $2 a)$. At day 7 , a small number of nestinGFP-positive cells were associated with single G261 cells of the emerging tumor (Fig. $2 b$ ). In contrast, at day 14 , the density of neural precursor cells around glioblastomas had augmented so strongly that the tumor was completely surrounded by a layer of nestin-GFP-positive cells (Fig. 2c). These cells had morphological features reminiscent of migratory cells; i.e., they exhibited bipolar morphology, extending long cellular processes from a central soma into two diametrically opposite directions (Fig. 2c, inset). These elongated nestinGFP-positive cells ensheathed the tumor in at least three or four cellular layers. Only a few glioblastoma cells invaded the brain parenchyma beyond the layer of the nestin-GFP-positive cells. Thirty days after tumor cell inoculation, nestin-GFPpositive cells around glioblastomas were less abundant than after $14 \mathrm{~d}$, and many tumor cells had invaded far into the brain parenchyma (Fig. 2d).

To distinguish whether the accumulation of nestin-GFPpositive cells is triggered by injury or is a specific response to a tumor, we compared the nestin-GFP expression in animals receiving tumor cells with others receiving sham operations (stab wounds). Accumulation of nestin-GFP-positive cells around the stab wound peaked $7 \mathrm{~d}$ after application of the lesion (Fig. 2e,f). After $14 \mathrm{~d}$, the nestin-GFP-positive cells had the stellar morphology of activated astrocytes and were evenly dispersed in the hemisphere (Fig. $2 g$, inset). Thirty days after the administration of the stab wound, only few nestin-GFP-positive cells were found in the injured hemisphere (Fig. 2h). Thus, in contrast to their association with glioma, nestin-GFP-positive cells gathered loosely around the stab wound with a peak after $7 \mathrm{~d}$ and acquired features of activated astrocytes, and then their number declined as described previously (Krum and Rosenstein, 1999).

Additional controls for grafts of glioblastoma cells included the injection of a nontumorigenic fibroblast cell line (scrc-1008) and primary cultured astrocytes. Neural precursor cells showed only a minor accumulation at these control grafts (results not shown). 


\section{Characterization of neural precursors surrounding glioblastomas}

Many nestin-GFP positive cells $(\sim 30 \%)$ around the tumors were actively dividing, as identified by colabeling with Ki67 (Fig. $3 a$ ), an antigen specifically present during cell division (Parkins et al., 1991). Singlechannel recordings for cellular markers (labeled blue), glioblastoma cells (labeled red), and neural precursor cells (labeled green) are displayed in Figure 3, next to overlay images and three-dimensional reconstructions of single cells. Figure 3, arrows, indicate colocalization of nestin-GFP with cellular markers in the single-channel micrographs and in the overlay pictures.

Nestin-GFP-positive cells surrounding the glioblastoma expressed several markers that allowed their further characterization as putative precursor cells. Approximately $35 \%$ of the nestin-GFP-positive cells expressed Musashi, an RNA-binding protein that is restricted to precursor cells (Okano et al., 2002) and suppresses commitment into the neuronal lineage (Fig. $3 b$ ). Tuc-4, a marker originally thought to be associated with the neuronal lineage but also found in precursor cells (Minturn et al., 1995), was expressed in many nestinGFP-positive cells (supplemental Fig. 2a, available at www.jneurosci.org as supplemental material), indicating a subspecification of these cells. Approximately 35\% of nestin-GFP-positive cells, expressed the chondroitin sulfate proteoglycan NG-2, a marker for glial precursors and neoplastic cells (Shoshan et al., 1999). Interestingly, NG-2 was colocalized with both nestinGFP-positive cells and the G261 tumor cells (Fig. 3c). Antibodies against two markers for migrating neural precursor cells (Chazal et al., 2000; Tanaka et al., 2004), PSA-NCAM (Fig. 3d) and doublecortin (DCx) (Fig. 3e) labeled $\sim 30 \%$ (PSA-NCAM) and 10\% (Dcx) of the nestin-GFP-positive cells in the proximity of the tumor.

GFAP is a classic marker for astrocytes but in the context of nestin expression and within the neurogenic regions of the adult brain also identifies the putative resident stem cells. Many precursor cells isolated from the adult brain are GFAP- and nestin-positive (Goldman, 2003). In the present study, GFAP was found in $\sim 60 \%$ of nestin-GFPpositive cells (Fig. $3 f$ ). This does not imply that they are stem cells in the sense of the neurogenic regions but sets them apart from other astrocytes. $\mathrm{S} 100 \beta$ as a marker for mature astrocytes (Holland, 2001) or calbindin as a neuronal marker (Gage, 2000) was not expressed in nestin-GFP-positive cells (supplemental Fig. $2 b, c$, available at www.jneurosci.org as supplemental material). $\mathrm{S} 100 \beta$, however, was expressed in the tumor cells as described previously for other glioblastoma cell lines (Morii et al., 1992). Only in a few nestin-GFP-positive cells did we detect coexpression of markers for the oligodendrocyte lineage (Godfraind et al.,

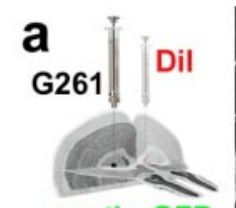

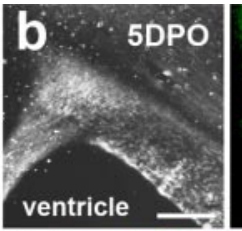
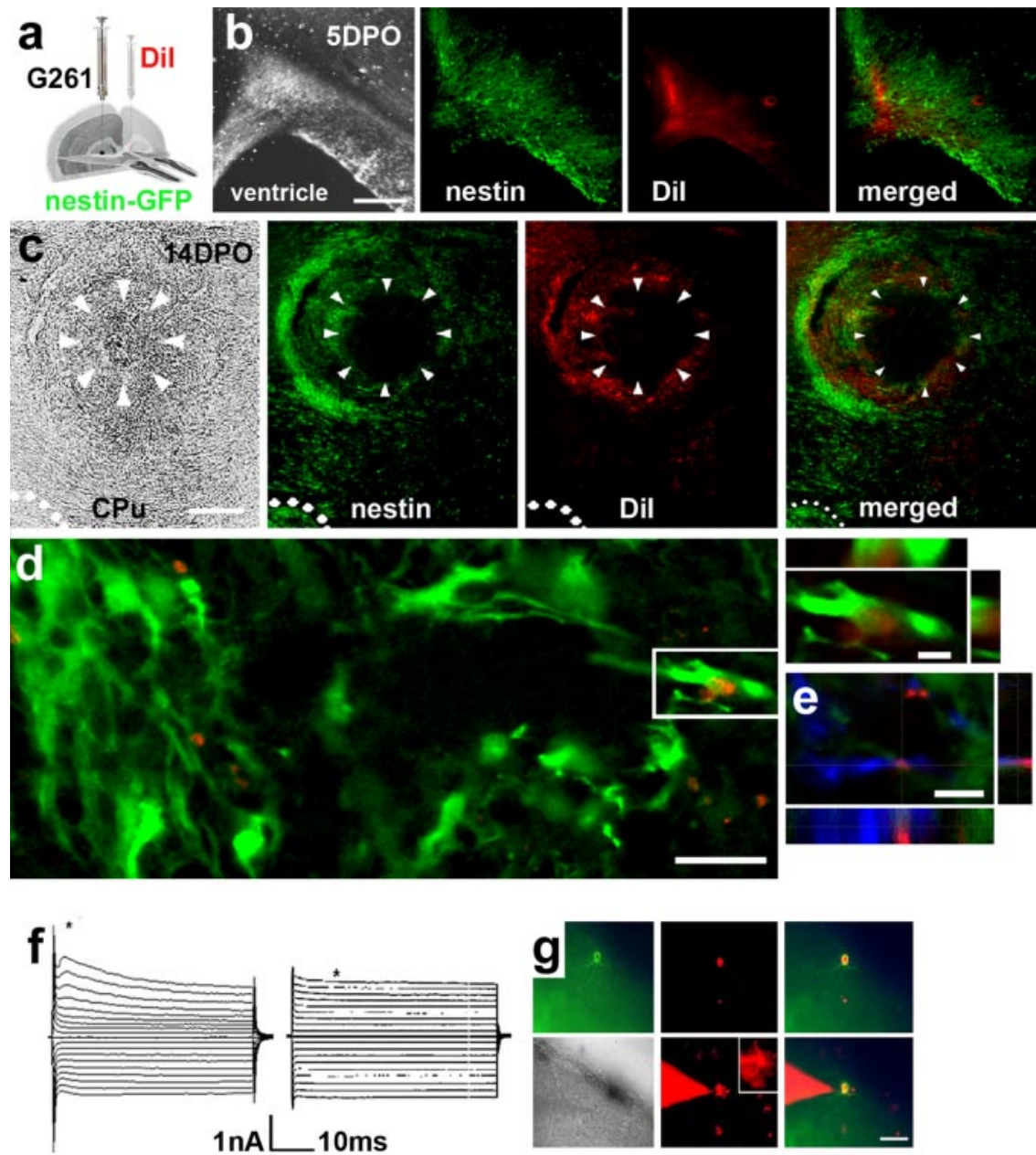

\section{1nAL 10ms}
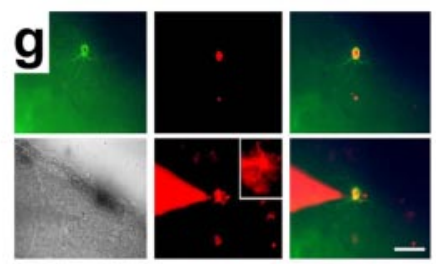

Figure 5. Neural precursors from the subventricular zone migrate toward glioblastomas. $\boldsymbol{a}$, Illustration of the location and uted in the ventricular and subventricular zones. c, At 14DP0, a glioblastoma has developed in the caudate-putamen (CPu) of a (nestin-GFP-positive) neural precursors emanating from the subventricular zone (pointed out , Distaining is located in nestin-GFP-positive neural precursor cells (3D reconstruction). $\boldsymbol{e}$, Triple-positive cell labeling for inactivating inward currents elicited with depolarization followed by outward currents. The threshold for activation of the inward $(\boldsymbol{f}$, left). A second population $(n=6)$ of Dil/nestin-GFP cells expressed passive, noninactivating currents with a linear currentvoltage relationship and a reversal potential of $-74 \mathrm{mV}(\boldsymbol{f}$, right). $\boldsymbol{h}$, Dil/nestin-GFP cells for electrophysiology could be application of the patch pipette was verified by dye filling; note that some neighboring cells are dye-coupled. Scale bars: $\boldsymbol{b}, \boldsymbol{c}, 400$ $\mu \mathrm{m} ; \boldsymbol{d}, 20 \mu \mathrm{m} ; 3 \mathrm{D}$ reconstructions, $6 \mu \mathrm{m} ; \boldsymbol{g}, 100 \mu \mathrm{m}$.

1989) such as the glycolipid O4 (results not shown) or the myelin protein $2^{\prime}, 3^{\prime}$-cyclic nucleotide $3^{\prime}$-phosphodiesterase (supplemental Fig. $2 d$, available at www.jneurosci.org as supplemental material). Labeling for markers for endothelial cells (isolectin B4 and von Willebrand factor) was absent from nestin-GFP-positive cells (results not shown).

\section{Neural precursors at glioblastomas originate from the} subventricular zone

We next addressed the question of whether the nestin-GFPexpressing cells were of local origin or migrated in from the germinal centers of the brain. Therefore, we labeled the dividing precursor cells of the brain with the thymidine analog BrdU before inoculation of glioblastomas (Fig. 4a). Fourteen days after tumor cell injection, 

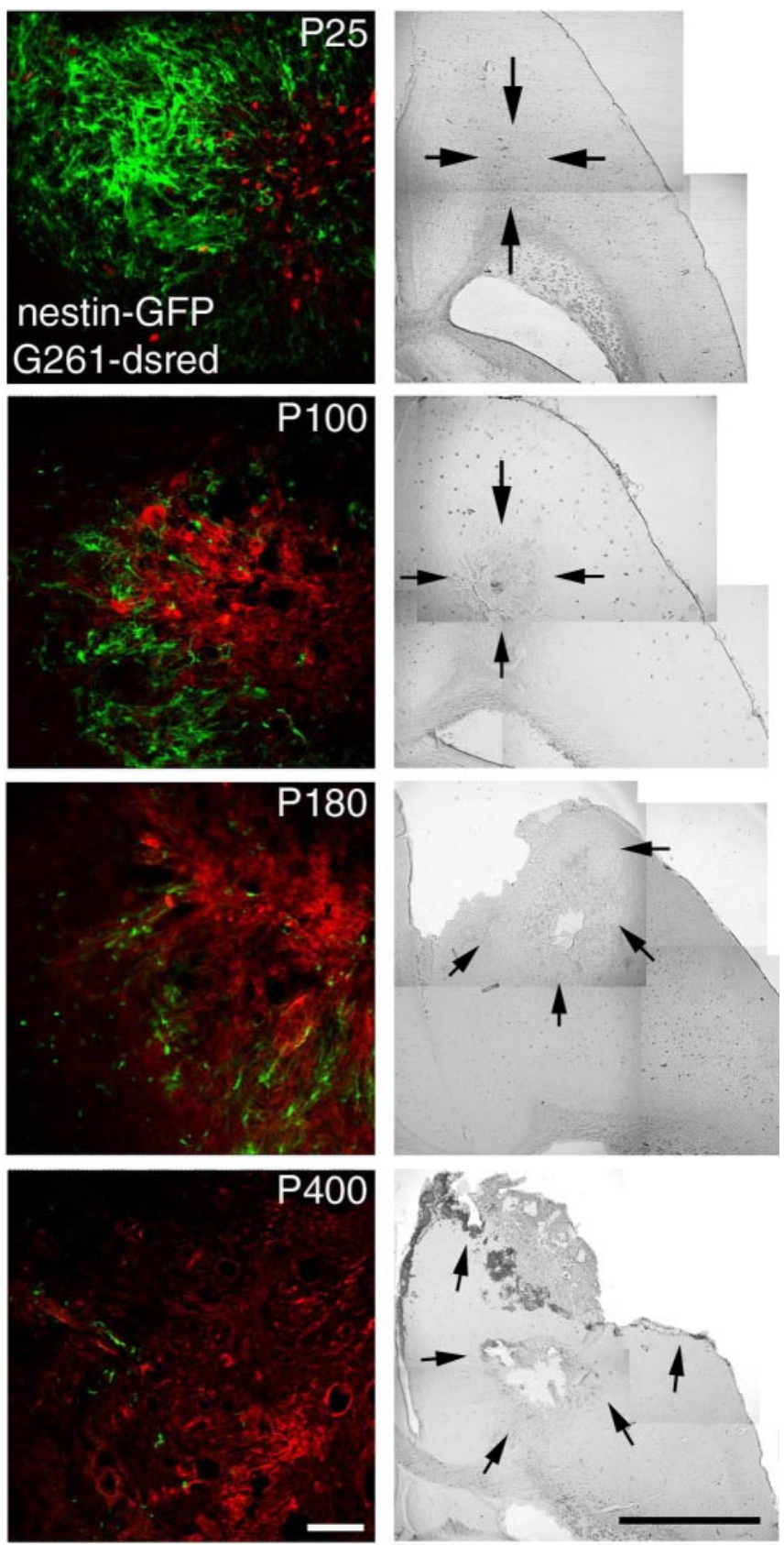

Figure 6. The decrease of neural precursors at glioblastomas in mice of increasing age relates to the severity of the pathology. The distribution and abundance of nestin-GFP-positive and tumor cells $14 \mathrm{~d}$ after inoculation was compared in animals at P25, P100, P180, and P400. The severity of the pathological state augmented with increasing age and is illustrated by representative phase contrast composite images, with arrows pointing out the extent of the main tumor mass. Glioblastomas in 100-d-old mice comprised a confined tumor mass, whereas in older mice, the G261 tumor cells invaded the brain parenchyma at P400, causing necrotic centers and local bleeding. Many nestin-GFP-positive cells surrounded the tumor in the 25-dold animals, whereas at P100, only single, but nevertheless large, patches of neural precursor cells were found. At P180 and P400, single scattered neural precursor cells were deeply embedded within the tumors. Scale bars: fluorescence images, $50 \mu \mathrm{m}$; phase contrast composites, $1 \mathrm{~mm}$.

the immediate surroundings of the tumor were immunopositive for both nestin-GFP and BrdU (Fig. 4b). Three-dimensional (3D) reconstruction of single cells demonstrates that GFP-expressing cells were colabeled for BrdU. Labeling for DsRed is absent because it was lost by the immunostaining procedure for BrdU.

In an additional set of experiments, we investigated whether the neural precursors derived from the subventricular zone, the densest germinative matrix in the brain. First, we established explant cultures of the subventricular zone of nestin-GFP mice and exposed these tissues to three-dimensional aggregates of G261DsRed glioblastoma cells. Within 5-7 d, many neural precursor cells had migrated into the area occupied by the tumor but not toward any area void of tumor cells (Fig. $4 c-e$ ). In control experiments, we investigated the tropism of neural precursors for other tissues such as another subventricular zone or for the cortex. In these experiments, we did not find migration of neural precursors toward the control tissues (Fig. $4 f-h$ ).

Second we studied whether the tropism of neural precursors is also present in vivo. Therefore, we administered the fluorescent dye DiI into the ventricle of the left brain hemisphere and thereby labeled all cells (ependymal and stem cells of both hemispheres) having direct contact to the fluid continuum of the ventricular system. Subsequently, we inoculated glioblastoma cells into the right hemisphere (Fig. 5a). Five days after the operation, DiIlabeled cells were distributed throughout the ventricular and subventricular zones of the tumor-bearing hemisphere, and few nestin-GFP/DiI-double-positive cells migrated toward the glioblastoma (Fig. $5 b$ ). Two weeks after the operation, bright labeling for both DiI and nestin-GFP was detected in the immediate vicinity of the tumor. DiI-positive cells were almost invariably nestin-GFP-positive, suggesting that they had migrated in from the subventricular zone to the tumor (Fig. $5 c, d$ ) (3D reconstructions). Triple labeling of nestin-GFP with DCx and DiI demonstrate that the DiI-positive cells are migrating neural precursors (Fig. 5e). These data indicate that proliferating neural precursors from the subventricular zone were attracted by the glioblastomas.

To further assess functional characteristics of cells colabeled for DiI and nestin-GFP (DiI/nestin-GFP cells), we studied their membrane current profile. Membrane currents of DiI/nestinGFP-double-positive cells were recorded in the tumor margin; the membrane potential was clamped for $50 \mathrm{~ms}$ to a series of depolarizing and hyperpolarizing potentials from a holding potential of $-70 \mathrm{mV}$. Whole-cell voltage-clamp recordings revealed the presence of voltage-gated outward currents in the majority of $\mathrm{DiI} /$ nestin-GFP cells. This current pattern is similar to the one described for type 2 neural progenitor cells in the hippocampus (Filippov et al., 2003). The remaining DiI and nestin-GFP cells exhibited passive membrane currents as described for astrocytes and the type 1 radial precursor cells (Fig. 5f,g).

\section{Attraction of precursors to glioblastomas declines with increasing age in murine specimens}

We compared accumulation of nestin-GFP-expressing cells and tumor growth $14 \mathrm{~d}$ after inoculation at the ages of 3.5 weeks (P25), 3 months (P100), 6 months (P180), and 13.5 months (P400). Whereas glioblastomas were relatively small and compact in mice at P25 (Fig. 6, P25), at P100 and P180, they increased in size, and the tumor border became more and more jagged and reached further into the surrounding parenchyma. At P400, the tumors extended over most of the brain hemisphere, frequently had necrotic centers, and often contained local bleedings, a clinical state rarely observed in younger animals after $14 \mathrm{~d}$ of tumor growth. In contrast to the young animals (P25), we found considerably fewer aggregates of neural precursor cells at the tumor margin in P100 mice. This situation became more obvious in 180 -d-old mice, where the aggregates containing neural precursor cells became scarce. In mice at P400, we found only a few neural precursor cells interspersed with the glioblastoma cells (Fig. 6). This reveals that in older subjects, precursor cells cannot 
a

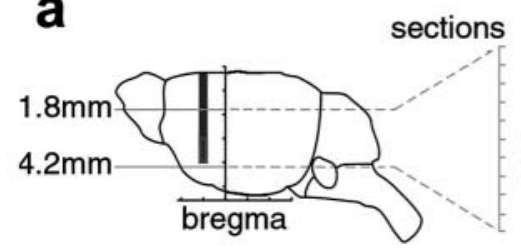

b

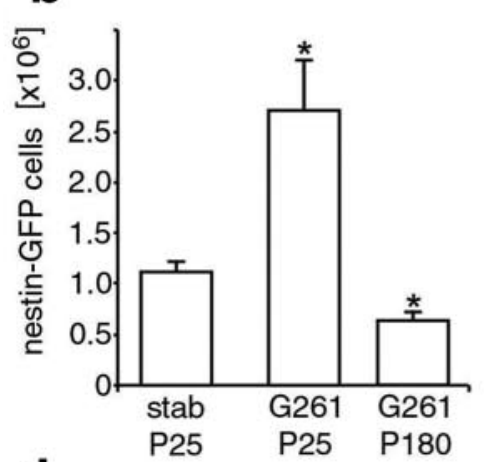

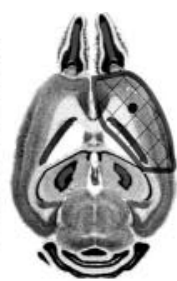

c

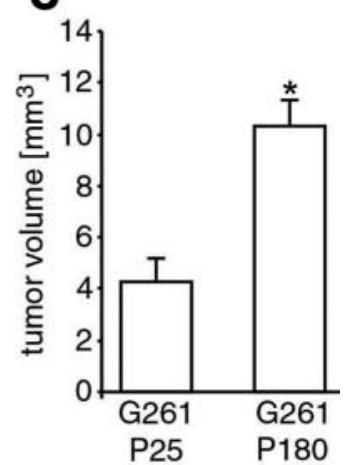

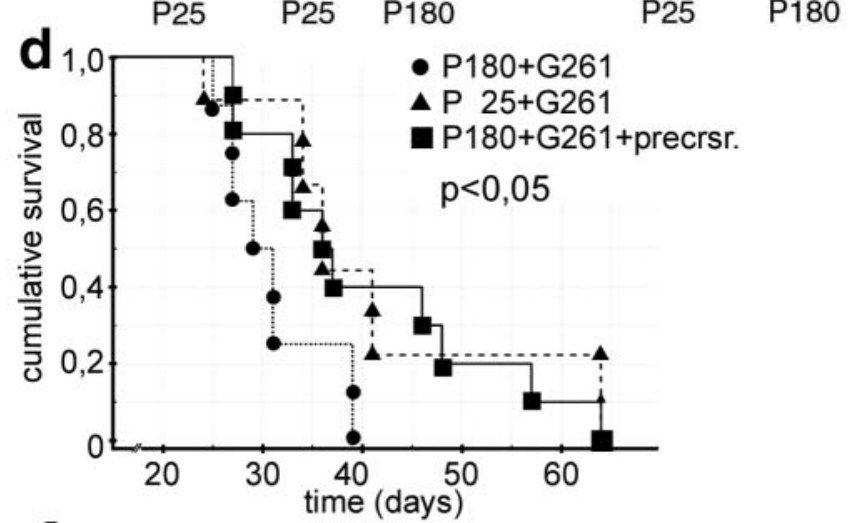
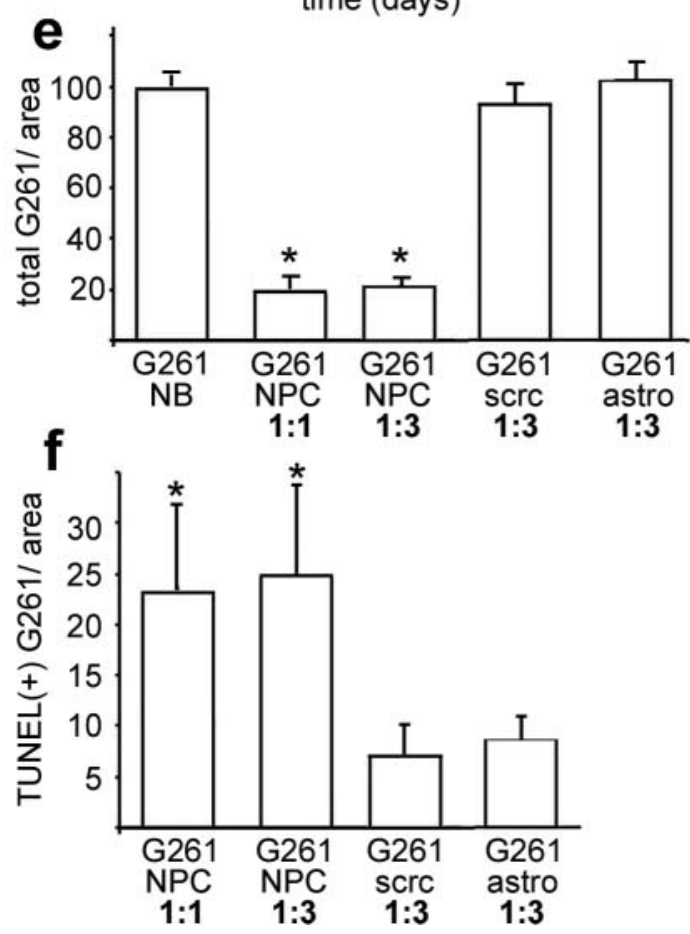

Figure 7. Neural precursors prolong survival of glioblastomas in vivo and are antitumorigenic in vitro. $\boldsymbol{a}$, Stereological cell counting of serial horizontal sections was performed in the area where the main tumor mass was located. The number of nestin-GFP-positive cells within the defined area $(\boldsymbol{b})$ was significantly $(p<0.05)$ larger in glioblastoma-bearing mice at P25 than in those of P180 or stab wound controls at P25 (b).c, The tumor volume in nestin-GFP mice be activated anymore to accumulate at the tumor. In addition, tumor growth inversely correlates with the abundance of neural precursor cells in the brain parenchyma.

Presence of neural precursors at glioblastomas is associated with decreased tumor size and improved survival

To quantify the difference in the nestin-GFP-positive cell population among the age groups, we counted nestin-GFP cells within one section in the subventricular zone, caudate-putamen, ventral cortex, and frontal cortex (Fig. 7a). Serial sections through brains of nestin-GFP mice were cut between 1.8 and $4.2 \mathrm{~mm}$ from the upper brain surface. Precursor cells were quantified frontal to the ventricular system and frontal to the temporal cortex excluding the olfactory bulb by unbiased stereological cell counting. Tumor volumes were estimated in a similar manner by the Cavalieri method.

In young mice, the number of nestin-GFP-positive cells $14 \mathrm{~d}$ after stab wound application was much lower $(\sim 40 \%)$ compared with tumor inoculation (Fig. $7 b$ ). One hundred eighty-day-old mice inoculated with G261 cells contained far fewer ( 20\%) precursor cells compared with glioblastoma-bearing 25 -d-old mice. In contrast, the tumor volume in the 180 -d-old mice was 2.5 times larger compared with young mice as evaluated using the Cavalieri method (Fig. 7c). These results indicate that in old mice, the pool of precursor cells is not recruited to the tumors, and, at the same time, their glioblastoma grow more vigorously. To determine the influence of neural precursor cells on tumor growth, we injected tumor cells either alone or together with neural precursor cells previously isolated from adult brain. We then compared the survival times after inoculation in three groups of nontransgenic recipients (Fig. $7 d$ ): one group of young (P25) and older mice (P180) received G261 tumor cells alone, whereas a third group of P180 mice obtained a 3:1 mixture of cultured adult neural precursor cells and G261 cells. Exogenously given neural precursors showed a response to glioblastomas similar to that of endogenous precursor cells. Fourteen days after the operation, the neural precursor cells remained at the glioblastoma and surrounded the tumor in several cell layers (supplemental Fig. 3, available at www.jneurosci.org as supplemental material).

Our results show that the cumulative survival of younger mice significantly exceeded that of older animals when only glioblastoma cells were administered. However, when neural precursor cells were coinjected with the glioblastoma cells, the older mice reached the same survival time as young animals.

Finally, we determined whether the neural precursors mediated a direct effect on glioblastoma cell numbers and whether the precursors were able to induce apoptosis of tumor cells. Coculturing of G261 cells together with neural precursors for $72 \mathrm{~h}$ mostly (by $80 \%$ ) and specifically (compared with controls) abro-

injected with G261-DsRed cells was significantly $(p<0.05)$ smaller in young animals (P25) and than in old ones (P180). d, Survival curves of young (P25+G261; $n=8$ ) and old (P180+G261; $n=9$ ) animals after G261 cell inoculation. The young animals survived significantly longer than the older but identically treated animals. However, when old mice (P180) were injected with a mixture of cultured adult neural precursor and G261 cells (P180+G261+ precrsr.; $n=10)$, the old animals survived better, similar to young mice. $\boldsymbol{e}$, Glioblastoma cells (G261) were either cultured in unconditioned precursor cell medium (NB) or cocultured with neural precursors (NPC) in different ratios (1:1 or 1:3); $G 261$ cells were also cocultured with scrc-1008 fibroblasts (scrc) and astrocytes (astro); after $72 \mathrm{~h}$, the number of G261 cells detected in cocultures with NPC was five times lower than in the controls.f, After $72 \mathrm{~h}$ of coculturing, the number of TUNEL-positive (apoptotic) G261 cells was four times greater in cocultures with NPC than in controls. 
gated the increase in cell number normally observed with these highly proliferative tumor cells (Fig. 7e). The rate of apoptosis was increased approximately four times in cocultures of glioblastomas and neural precursors compared with controls within the 72 h observation time (Fig. $7 f$ ).

\section{Discussion}

In summary, our data indicate that endogenous neural precursor cells have a strong tropism for glioblastomas in vivo. The abundance of neural precursors at the tumor is associated with reduced tumor size and increased survival as studied in an animal model, and in vitro, precursor cells have a direct antitumorigenic effect. Such antitumorigenic effects have been described previously for exogenously added immortalized neural precursor cells from newborn mice (Benedetti et al., 2000; Staflin et al., 2004), but in those studies, no relationship to endogenous, nonimmortalized precursor cells could be established. Implanted immortalized precursors display tropism for experimental glioblastomas (Aboody et al., 2000). Both tropism and the antitumorigenic effect have been subjects of discussion. Here, we show that the presence of acutely isolated nonimmortalized primary adult precursor cells at a glioblastoma is correlated with improved survival. Furthermore, the accumulation of endogenous precursors is likely to resemble a normal intrinsic tissue response to tumors because the substantial tropism of precursor cells to the tumor could not be initiated by any other lesion such as stab wounds or injection of nontumorigenic cells. The tropism of neural precursor cells for glioblastomas persisted in noninjured areas. G261 cells invaded from the injection site in the caudate-putamen far into the brain and reached the striatum, where we frequently observed neural precursors in close proximity to the tumor cells. Finally, neural precursors from subventricular explant cultures migrated toward glioblastoma aggregates but not toward other tissue, indicating that precursor cells are specifically attracted to the tumor.

Glioblastomas can originate from neural precursors undergoing misregulated proliferation or differentiation (Holland et al., 2000), and a recent series of studies demonstrated that glioblastomas contain a highly aggressive subpopulation of cancer stem cells (Hemmati et al., 2003; Singh et al., 2003; Galli et al., 2004; Singh et al., 2004). We extent the current view on the relation between precursor cells and glioblastomas by demonstrating that endogenous neural precursor cells also respond to existing tumors and mediate effects beneficial for the tumor host.

We observed the accumulation of neural precursors at a glioblastoma over time and discovered a transient increase of precursors at the tumor, which peaked at $\sim 14 \mathrm{~d}$ after tumor inoculation but then had declined by the 30th postoperative day. The reduction of precursor cell numbers at the tumor may be a sign of progressive differentiation of the precursors, which could be initiated by the growth factors secreted from the tumor. Factors such as insulin-like growth factor I are secreted from glioblastoma cells (Trojan et al., 1993; Hirano et al., 1999) and can promote neural precursor cell differentiation (Arsenijevic and Weiss, 1998). The secretion of such factors may be necessary for the glioblastoma to prevail over the precursors surrounding the tumor, and with increasing tumor size, more growth factors are released.

The neural precursor cells in our model originate from the subventricular zone and have migrated over a long distance toward the tumor. Our study provides evidence that glioblastomas attract precursor cells from the subventricular zone to form a tissue enwrapping the tumor. The abundance of neural precur- sors accumulating in the immediate vicinity of glioblastomas was inversely correlated with the severity of the pathology. In experiments using animals of increasing age, we observed fewer neural precursors at the tumor, concomitant with an increase in tumor size, frequency of local bleedings, and extent of tissue destruction. Exogenously added neural precursors in older mice prolonged survival of glioblastomas. The ability of neural precursors to directly interfere with tumor cell expansion was demonstrated in vitro. Coculturing precursors with glioblastoma cells led to an abrogation of the normally rapid increase in total cell number of these tumors and strongly induced tumor cell apoptosis.

In addition to the direct induction of tumor cell death by precursor cells, the increasingly severe course of pathology observed in the oldest group of animals may also be tolerated by a declining immune response. Old mice with an average age of approximately $\mathrm{P} 600$ have significantly less CD8 ${ }^{+}$T-cells compared with animals of $\sim \mathrm{P} 300$, resulting in decreased survival to experimental glioblastomas (Wheeler et al., 2003). However, in the age groups compared in the present study, these immune effects are not likely to be preponderant. The total number of thymocytes initially declines during development in young mice but then remains constant until P200 (Ortman et al., 2002). In our experiments, we observed consistently more severe lesions up to P180 and beyond, parallel to a steep decline in precursor cell number. The moderate decline in microglial cells during aging (Ma et al., 2003) is probably not related to tumor progression either because microglia cannot perform an effective defense against glioblastoma (Graeber et al., 2002).

Although nestin-GFP-positive cells showed signs of immature neuronal marker expression (DCx and PSA-NCAM), the impairing effect on tumor growth is mediated by an interaction between precursor and tumor cells rather than by a replacement of lost brain cells by the precursors. This response can be interpreted as an attempt of intrinsic antitumorigenic activity or even regeneration that ultimately succumbs to the invasiveness of the tumor. In young subjects with a large endogenous precursor cell pool, this response might be more prominent than in older patients that have a declined precursor cell population. Therefore, it is possible that juveniles profit from antitumorigenic effects mediated by the neural precursor cells. In this respect, it is interesting that glioblastomas are rare in younger patients but statistically peak in subjects of $\sim 55$ years of age. Children develop other kinds of brain tumors such as medulloblastomas (Kleihues et al., 1996), and it remains to be determined whether these tumors can also initiate the attraction of neural precursor cells. Our data suggest that a strong intrinsic precursor cell response can control glioblastoma growth, and this control fails once the number of endogenous precursor cells decreases with increasing age.

\section{References}

Aboody KS, Brown A, Rainov NG, Bower KA, Liu S, Yang W, Small JE, Herrlinger U, Ourednik V, Black PM, Breakefield XO, Snyder EY (2000) Neural stem cells display extensive tropism for pathology in adult brain: evidence from intracranial gliomas. Proc Natl Acad Sci USA 97:12846-12851.

Arnhold S, Hilgers M, Lenartz D, Semkova I, Kochanek S, Voges J, Andressen C, Addicks K (2003) Neural precursor cells as carriers for a gene therapeutical approach in tumor therapy. Cell Transplant 12:827-837.

Arsenijevic Y, Weiss S (1998) Insulin-like growth factor-I is a differentiation factor for postmitotic CNS stem cell-derived neuronal precursors: distinct actions from those of brain-derived neurotrophic factor. J Neurosci 18:2118-2128.

Benedetti S, Pirola B, Pollo B, Magrassi L, Bruzzone MG, Rigamonti D, Galli R, Selleri S, Di Meco F, De Fraja C, Vescovi A, Cattaneo E, Finocchiaro G 
(2000) Gene therapy of experimental brain tumors using neural progenitor cells. Nat Med 6:447-450.

Chazal G, Durbec P, Jankovski A, Rougon G, Cremer H (2000) Consequences of neural cell adhesion molecule deficiency on cell migration in the rostral migratory stream of the mouse. J Neurosci 20:1446-1457.

Filippov V, Kronenberg G, Pivneva T, Reuter K, Steiner B, Wang LP, Yamaguchi M, Kettenmann H, Kempermann G (2003) Subpopulation of nestin-expressing progenitor cells in the adult murine hippocampus shows electrophysiological and morphological characteristics of astrocytes. Mol Cell Neurosci 23:373-382.

Gage FH (2000) Mammalian neural stem cells. Science 287:1433-1438.

Galli R, Binda E, Orfanelli U, Cipelletti B, Gritti A, De Vitis S, Fiocco R, Foroni C, Dimeco F, Vescovi A (2004) Isolation and characterization of tumorigenic, stem-like neural precursors from human glioblastoma. Cancer Res 64:7011-7021.

Godfraind C, Friedrich VL, Holmes KV, Dubois-Dalcq M (1989) In vivo analysis of glial cell phenotypes during a viral demyelinating disease in mice. J Cell Biol 109:2405-2416.

Goldman S (2003) Glia as neural progenitor cells. Trends Neurosci 26:590-596.

Graeber MB, Scheithauer BW, Kreutzberg GW (2002) Microglia in brain tumors. Glia 40:252-259.

Hallbergson AF, Gnatenco C, Peterson DA (2003) Neurogenesis and brain injury: managing a renewable resource for repair. J Clin Invest 112:1128-1133.

Hamill OP, Marty A, Neher E, Sakmann B, Sigworth FJ (1981) Improved patch-clamp techniques for high-resolution current recording from cells and cell-free membrane patches. Pflügers Arch 391:85-100.

Hemmati HD, Nakano I, Lazareff JA, Masterman-Smith M, Geschwind DH, Bronner-Fraser M, Kornblum HI (2003) Cancerous stem cells can arise from pediatric brain tumors. Proc Natl Acad Sci USA 100:15178-15183.

Heussen C, Dowdle EB (1980) Electrophoretic analysis of plasminogen activators in polyacrylamide gels containing sodium dodecyl sulfate and copolymerized substrates. Anal Biochem 102:196-202.

Hirano H, Lopes MB, Laws Jr ER, Asakura T, Goto M, Carpenter JE, Karns LR, VandenBerg SR (1999) Insulin-like growth factor-1 content and pattern of expression correlates with histopathologic grade in diffusely infiltrating astrocytomas. Neuro-oncol 1:109-119.

Holland EC (2001) Gliomagenesis: genetic alterations and mouse models. Nat Rev Genet 2:120-129.

Holland EC, Celestino J, Dai C, Schaefer L, Sawaya RE, Fuller GN (2000) Combined activation of Ras and Akt in neural progenitors induces glioblastoma formation in mice. Nat Genet 25:55-57.

Iwasaki K, Kikuchi H, Miyatake S, Kondo S, Oda Y (1992) Establishment of a new cell line derived from a human gliosarcoma. Neurosurgery 30:228-235.

Kempermann G, Gast D, Kronenberg G, Yamaguchi M, Gage FH (2003) Early determination and long-term persistence of adult-generated new neurons in the hippocampus of mice. Development 130:391-399.

Kleihues P, Burger PC, Scheithauer BW (1996) Histological typing of the tumors of the central nervous system, Ed 2. Stuttgart, Germany: Springer.

Koul D, Parthasarathy R, Shen R, Davies MA, Jasser SA, Chintala SK, Rao JS, Sun Y, Benvenisite EN, Liu TJ, Yung WK (2001) Suppression of matrix metalloproteinase-2 gene expression and invasion in human glioma cells by MMAC/PTEN. Oncogene 20:6669-6678.

Krum JM, Rosenstein JM (1999) Transient coexpression of nestin, GFAP, and vascular endothelial growth factor in mature reactive astroglia following neural grafting or brain wounds. Exp Neurol 160:348-360.

Lendahl U (1997) Gene regulation in the formation of the central nervous system. Acta Paediatr Suppl 422:8-11.

Liu C, Yao J, Mercola D, Adamson E (2000) The transcription factor EGR-1 directly transactivates the fibronectin gene and enhances attachment of human glioblastoma cell line U251. J Biol Chem 275:20315-20323.

Lyons SA, Kettenmann H (1998) Oligodendrocytes and microglia are selectively vulnerable to combined hypoxia and hypoglycemia injury in vitro. J Cereb Blood Flow Metab 18:521-530.

Ma L, Morton AJ, Nicholson LF (2003) Microglia density decreases with age in a mouse model of Huntington's disease. Glia 43:274-280.

Maslov AY, Barone TA, Plunkett RJ, Pruitt SC (2004) Neural stem cell detection, characterization, and age-related changes in the subventricular zone of mice. J Neurosci 24:1726-1733.

Minturn JE, Geschwind DH, Fryer HJ, Hockfield S (1995) Early postmitotic neurons transiently express TOAD-64, a neural specific protein. J Comp Neurol 355:369-379.

Morii K, Tanaka R, Takahashi Y, Kuwano R (1992) Cloning of cDNAs encoding human S-100 alpha and beta subunits and their differential expression in human tumor cell lines. J Neurosci Res 32:27-33.

Noble M (2000) Can neural stem cells be used to track down and destroy migratory brain tumor cells while also providing a means of repairing tumor-associated damage? Proc Natl Acad Sci USA 97:12393-12395.

Okano H, Imai T, Okabe M (2002) Musashi: a translational regulator of cell fate. J Cell Sci 115:1355-1359.

Ortman CL, Dittmar KA, Witte PL, Le PT (2002) Molecular characterization of the mouse involuted thymus: aberrations in expression of transcription regulators in thymocyte and epithelial compartments. Int Immunol 14:813-822.

Palmer TD, Takahashi J, Gage FH (1997) The adult rat hippocampus contains primordial neural stem cells. Mol Cell Neurosci 8:389-404.

Parkins CS, Darling JL, Gill SS, Revesz T, Thomas DG (1991) Cell proliferation in serial biopsies through human malignant brain tumors: measurement using Ki67 antibody labeling. Br J Neurosurg 5:289-298.

Ponten J, Westermark B (1978) Properties of human malignant glioma cells in vitro. Med Biol 56:184-193.

Shoshan Y, Nishiyama A, Chang A, Mork S, Barnett GH, Cowell JK, Trapp BD, Staugaitis SM (1999) Expression of oligodendrocyte progenitor cell antigens by gliomas: implications for the histogenesis of brain tumors. Proc Natl Acad Sci USA 96:10361-10366.

Singh SK, Clarke ID, Terasaki M, Bonn VE, Hawkins C, Squire J, Dirks PB (2003) Identification of a cancer stem cell in human brain tumors. Cancer Res 63:5821-5828.

Singh SK, Hawkins C, Clarke ID, Squire JA, Bayani J, Hide T, Henkelman RM, Cusimano MD, Dirks PB (2004) Identification of human brain tumor initiating cells. Nature 432:396-401.

Staflin K, Honeth G, Kalliomaki S, Kjellman C, Edvardsen K, Lindvall M (2004) Neural progenitor cell lines inhibit rat tumor growth in vivo. Cancer Res 64:5347-5354.

Tanaka T, Serneo FF, Tseng HC, Kulkarni AB, Tsai LH, Gleeson JG (2004) Cdk5 phosphorylation of doublecortin ser297 regulates its effect on neuronal migration. Neuron 41:215-227.

Trojan J, Johnson TR, Rudin SD, Ilan J, Tykocinski ML (1993) Treatment and prevention of rat glioblastoma by immunogenic C6 cells expressing antisense insulin-like growth factor I RNA. Science 259:94-97.

Westermark B, Ponten J, Hugosson R (1973) Determinants for the establishment of permanent tissue culture lines from human gliomas. Acta Pathol Microbiol Scand [A] 81:791-805.

Wheeler CJ, Black KL, Liu G, Ying H, Yu JS, Zhang W, Lee PK (2003) Thymic CD8 + T cell production strongly influences tumor antigen recognition and age-dependent glioma mortality. J Immunol 171:4927-4933.

Zhang H, Kelly G, Zerillo C, Jaworski DM, Hockfield S (1998) Expression of a cleaved brain-specific extracellular matrix protein mediates glioma cell invasion in vivo. J Neurosci 18:2370-2376.

Zhang H, Vutskits L, Pepper MS, Kiss JZ (2003) VEGF is a chemoattractant for FGF-2-stimulated neural progenitors. J Cell Biol 163:1375-1384. 